\title{
Analysis Of Academic Fraud Of Student In Unversity Based On Fraud Pentagon Theory
}

\author{
Octavia Lhaksmi Pramudyasututi ${ }^{1)}$, Nuwun Priyono ${ }^{2)}$, Utpala Rani ${ }^{3)}$, Danar Putri Miranda ${ }^{4}$, \\ \{octaviaovi@untidar.ac.id ${ }^{1}$, nuwunpriyono@untidar.ac.id ${ }^{2}$, utpala@untidar.ac.id ${ }^{3}$, \\ danarputri82@gmail.com 4 \} \\ Universitas Tidar, Indonesia ${ }^{1}$, Universitas Tidar, Indonesia ${ }^{2}$, Universitas Tidar, Indonesia $^{3}$, \\ Universitas Tidar, Indonesia ${ }^{4}$
}

\begin{abstract}
Academic fraud is a serious problem related to integrity and ethics that occurs in every educational institution. This study aims to identify the causes of academic fraud behavior among students at state universities in Magelang based on the Pentagon theory of fraud dimensions. This research is a qualitative study using a case study approach. Data were collected by means of observation and interviews with 15 respondents of undergraduate and diploma level students. Based on the results of the study, it can be concluded that the act of student academic cheating is caused by five main aspects, namely pressure, opportunity, rationalization, ability and finally the student's personal arrogance. A student does not commit academic fraud if one aspect is not fulfilled. Some actions that must be taken to minimize fraud are improving the assessment system and examination supervision, improving the quality of the lecture process, establishing strict sanctions, evaluating regular academic guidance and guidance, and also organizing non-academic programs to improve the balance of IQ, EQ., SQ, and AQ.
\end{abstract}

Keywords: academic fraud, students, fraud pentagon theory.

\section{Introduction}

Indonesia is one of the developing countries which has serious corruption cases. The government establishes various policies to handle, minimize and prevent corruption cases. At present, corruption in Indonesia is not only committed by unscrupulous officials in the government sector, but has entered many other sectors. There have been many corruption criminal cases involving large and small companies, as if corruption has become a crime that is no longer feared.

Several cases of corruption have ensnared both private companies and State-Owned Enterprises (BUMN) including PT. Pelindo II, PT. Jiwasraya, PT. Century Bank, Pt Hansol Internasional, and PT ASABRI. The fraud that occurs in these cases is a form of financial fraud that violates financial recording and reporting regulations, as well as a very serious fraud.

These cases of fraud cannot be separated from the individuals who work in the company and the leaders who are in control of the decisions therein. The head of the company became a suspect and was responsible for fraud committed by the company. These cases show that the role of a decision maker greatly affects the company.

These cases show that a leader does not necessarily have high integrity and morality. Leaders with unquestionable intellectual degrees and competence in their fields should be able to make good decisions. However, it turns out that there are still many high-ranking private companies and BUMNs in Indonesia who commit fraud. This is of course in contrast to the educational degree attached to them, where higher education becomes a means of learning about 
Ethics and Professionalism properly and consistently which is expected to be implemented in the future.

The cases of cheating that are very prevalent today are not far from the phenomenon of academic cheating that occurs in universities as a forerunner to the habit of cheating that may be committed in the future. Academic cheating by many students in various forms reflects the habit of cheating that has been done since adolescence until it is no longer taken seriously. Because of this, it is necessary to have special research to investigate the causes of the occurrence of academic fraud among students, as well as to find solutions to deal with, minimize and prevent these acts of academic fraud as an effort to help tackle corruption.

One of the previous studies that initiated the study of academic fraud was the research conducted by [1] which raised the investigation of the fraud triangle in determining aspects that influence student academic fraud. The fraud triangle put forward by Donald R is a theory used to analyze fraud with three factors, namely pressure, opportunity, and rationalization. In a further study, in her research revealed a new factor in the theory of fraud which also has a significant influence on fraud committed by students. In his research, Rahmalia Nursani used the Fraud Diamond theory proposed by [2] adding a new factor, namely as a factor that influences cheating behavior.

From the results of previous research, then revealed a new theory, namely the Fraud Penthagon Theory where there are five factors that influence a person to commit fraud. The five factors are pressure, opportunity, rationalization, ability, and arrogance. In the Fraud Penthagon Theory, it is said that the frequent number of CEO's picture is indicated to lead to fraud.

Based on the findings of the new theory about cheating, the researcher wants to investigate the causes of academic fraud behavior among state and private tertiary institutions in Magelang City based on Fraud Penthagon Theory, namely pressure, opportunity, rationalization, ability, and arrogance and identify solutions that can be done as an effort to overcome , minimize, and prevent student academic fraud behavior based on the Penthagon Fraud dimension.

\subsection{Literatur Review}

\section{Academic Cheating}

Cheating is an act that violates the rules carried out to achieve certain individual goals. IAPI (2013) states that fraud or fraud is an intentional act by one or more individuals in management or those responsible for governance, employees, and third parties that involve the use of deception to gain an advantage unfairly or violate the law. Cheating behavior can occur in various areas of life and also in all environments. Cheating does not only occur in the profitoriented business sector, but also in the non-profit sector, one of which is academic institutions, which is then referred to as academic fraud. Fraud is not always related to the search for material assets, but can be due to the search for achievement or prestige.

Academic fraud is an act that violates ethics. Many students commit academic fraud without realizing that these actions violate ethics. Academic cheating is committed by students in almost all academic processes, from the learning process to thesis writing. Academic fraud committed by students is very diverse and for various reasons. 
states that at Arizona State University the category of academic cheating is divided into five categories, namely:
a. Plagiarism
b. Data falsification, for example making scientific data which is fictitious data
c. Multiple assignments, namely submitting the same two papers to two different classes without the permission of the lecturer.
d. Cheating on exams
e. Wrong cooperation

\section{Fraud Pentagon Theory}

Pada tahun 2004, menurut The CPA Journal, Wolfe dan Hermanson menemukan teori baru mengenai penyebab tindakan fraud. Mereka menyebutkan bahwa pengembangan teori baru ini dalam rangka meningkatkan pencegahan dan pendeteksian fraud. Aspek-aspek Diamond Fraud Theory terdiri dari Insentif (Tekanan), Peluang, Rasionalisasi, dan aspek baru yaitu kapabilitas atau kemampuan. Penambahan aspek kemampuan berdasarkan pengalaman Wolfe dan Hermanson yang menjadi investigator kecurangan selama 15 tahun dan menemukan fakta bahwa: pertama, orang-orang yang melakukan kecurangan adalah seseorang yang memiliki kedudukan yang tinggi dan berpeluang besar melakukan kecurangan. Kedua, seseorang yang melakukan kecurangan adalah seseorang yang cerdas yang mengeksploitasi kelemahan pengendalian internal dan menggunakan posisinya untuk mengambil keuntungan yang sebesarbesarnya.

\section{Methodology}

This research is a qualitative research using a case study approach. Selection of case studies aims to save time and make it easier for researchers to explore problems within certain limits, and include various sources of information. Data collection used was observation and interviews.

This research is a case study of the factors that cause student academic fraud at tertiary institutions in Magelang. The data for this study were obtained by conducting observations and interviews with 15 respondents consisting of 5 STMIK Bina Patria students, 5 Muhammadiyah Magelang University students, and 5 students from Tidar University. Researchers want to see students' perceptions of their academic cheating behavior based on the Fraud Penthagon Theory Concept as well as criticism from respondents for an effective learning process to minimize academic cheating behavior.

\section{Finding and Discussion}

This research uses Pentagon Theory Fraud investigation, which is the development of the previous findings, the Fraud Triangle Theory. The difference from Fraud Pentagon Theory is the addition of a fifth aspect, namely the arrogance of the perpetrators of fraud. Researchers use aspects of pressure, opportunity, rationalization, ability, and arrogance as aspects that encourage student academic fraud.

\subsection{Pressure and Academic Cheatig}

According to the Big Indonesian Dictionary (2020), pressure has the meaning of a strong pressure or coercion which is sometimes unpleasant and becomes an inner burden. Pressure is an unpleasant and very annoying thing for everyone. Pressure can cause stress and even 
depression. Pressure makes people do things that are not good because they are mentally disturbed by something that makes them stressed.

The results of the study stated that respondents confirmed that pressure could make someone commit fraud. As many as 6 out of 15 respondents stated that their acts of cheating were caused by interventions against them from outside or from within. Pressure that comes from outside can be in the form of demands from parents for academic achievement that is too high but unable to provide understanding to children, demands to be able to finish college and graduate on time, demands from campus that come from academic regulations, competition between students in academic fields (prestige) and the requirements for seeking educational scholarships. There were several respondents who admitted that the pressure to find scholarships due to intense competition made them commit fraud. The pressure factor of Fraud Pentagon Theory provides a statement that academic cheating behavior can start from the presence of strong pressure or encouragement from various sources. One type of pressure can be a compelling reason for a student to commit academic fraud. Students who experience various pressures will have the potential to commit cheating. Thoose, the solution that can be offered is to control their own mental health or if the pressure they are experiencing is quite heavy, students can immediately contact the lecturer for academic consultation.

\subsection{Opportunity and Academic Cheating}

Opportunity is a situation where someone gets lucky or something that is profitable for them. Based on the results of interviews with all respondents, it was concluded that the opportunity for academic fraud was due to system weaknesses in the learning system. Several arguments were found by students regarding the weaknesses of the assessment and learning system, including: a weak examination supervision system, the application of indecisive sanctions, and the lecturer did not correct the exam or assignment seriously.

The most frequent act of cheating by students during exams is cheating and carrying notes on paper or placed in a hidden place. Students often repeat this action every time they take a test. According to them, the existing surveillance system is loose enough to be rigged. Respondents admitted that the opportunities during the exam caused by the exam supervisor or by the lecturers or students themselves could bring the stolen perfume case up to the national realm.

In the learning process, sometimes there are lecturers who are not serious in researching student work and answers, thus opening opportunities for students to commit academic fraud in the form of plagiarism or plagiarism. Where plagiarism is the biggest crime in academia. The results of the interviews showed that the teaching staff had a big influence, in this case the lecturers, in forming opportunities or opportunities for academic cheating behavior.

\subsection{Academic Rationalization and Fraud}

There are various rationalization reasons made by students as an excuse for them committing academic fraud. The reason most justified by students was the assumption that cheating was the result of the system being implemented that was too loose and had many loopholes to be cheated. In addition, some of the respondents said that the cheating they committed would be tolerated because some lecturers did not really pay attention to it. According to respondents who often commit acts of cheating in the form of plagiarism or cheating on routine assignments of courses, this action is not wrong, because the lecturers do not oppose them to cooperate, even though the assignment given is an individual task. 
The next rationalization is about lecturers who are not serious in providing material, so that students have difficulty understanding the material. The rationalization regarding the understanding of this material actually is not a pure fault of the lecturers or teaching staff, but also students. Majority of respondents admitted that they were sometimes not quite ready to receive the material and instead looked for references and studied the material independently, thus committing academic fraud.

The reason for the next rationalization is the very short time for assignments from the lecturer. A total of 5 respondents stated that there are lecturers who only give a deadline of one to two hours to submit assignments. Respondents perceive this as pressure that makes respondents justify cheating just so they can complete their assignments on time.

The last rationalization is about the test that is difficult for them to do and the test time is small. Actually this is not justified. Because the problem is that the exam is designed to measure students' abilities. However, students often use this rationalization to commit cheating. This was revealed by 10 out of 15 respondents.

Rationalization strengthens other aspects of Fraud Pentagon Theory. Without rationalization, the act of cheating will definitely never done because cheating is against the ethical understanding of an offender.

\subsection{Capabilities and Fraud}

The student capability in question is the student's ability to analyze opportunities to commit fraud. This ability is then accompanied by information about system weaknesses and other opportunities so that students feel capable of cheating. 7 out of 15 respondents stated that they felt they had the ability to safely cheat. Respondents have various strategies for cheating, including by exchanging answers with other classes that have already carried out tests or exams. Another strategy is to invite friends to work together and exchange answers.

Wolfe and Hermanson [2] (2004) conclude that without the ability or capability of the perpetrator, the fraudulent act will not occur. This is in line with the answers of respondents who stated that they must feel capable so that they are confident in acting fraudulently. Respondents added that the basic abilities possessed in cheating are the ability to invite and convince friends as well as the ability to analyze the types of lecturers in teaching and provide academic assessments to students. Through this analysis, students can determine what cheating can be done without getting caught.

\subsection{Arrogancy and Fraud}

Arrogance according to the Big Indonesian Dictionary (KBBI) means "keangkuhan atau kesombongan yang muncul dari dalam diri seseorang". The last aspect raised in the Fraud Pentagon is the arrogance of the perpetrators. With the arrogance of the perpetrator, it will encourage self-confidence and courage to cheat. Arrogance as the last aspect put forward by Cressey is an aspect that respondents assessed as encouraging students to act fraudulently. This is due to the prestige and prestige they have to the arrogance of those who think that they are capable of being released from sanctions due to the violations they have committed.

As many as 6 out of 15 respondents admitted that they have arrogance that encourages them to commit fraud. This happens because they think that the existing system is unable to provide a deterrent effect on them. This proves that arrogance is an aspect that has a significant effect on student cheating. 


\subsection{Academic Fraud Prevention Measures Based on Pentagon Fraud Perceptions Pressure Aspect}

Academic fraud is behavior that violates various aspects, not only violating academic regulations, but also violating ethics and morals. Dishonesty that starts early is very dangerous. Moreover, lies committed in the world of education are very destructive to morals. The education sector, in this case higher education, should be a domain that can avoid cheating that can create leaders without morals. The various impacts caused by this disgraceful behavior are the seeds of other unacceptable behavior in a more serious future. The younger generation who are the successors of life will do what they think is right for their personal gain.

As the top of education, universities need to take seriously the cheating behavior that occurs in academic activities in the campus education environment. Several things can be done to be able to overcome, minimize, and prevent the occurrence of cheating by students, based on the significant influence generated from the five Fraud Pentagon Theory specs. Some things that can be done regarding these five aspects are as follows.

Based on observations, researchers stated that pressure is an aspect of driving academic fraud. The aspect of pressure that comes from a psychological side causes an impact on someone's behavior that is irrational and moral. This aspect of pressure causes a person to behave so that he no longer feels pressure. Some things that can be done as preventive measures for this aspect of pressure are to provide guidance to students personally, provide activities that are able to prevent students from committing fraud by observing student personalities. Then, the institution can hold seminars on psychology and provide spiritual and mental guidance so that good morals continue to be built (balance IQ, EQ, SQ, AQ).

\section{Opportunity Aspects}

The opportunity aspect relates to the internal control system. If an institution has a good internal control system, fraud can be anticipated and minimized. In a discussion of the relationship between academic cheating and the aspect of opportunity, it can be concluded that academic cheating behavior occurs due to an inadequate internal control system. Several stages that can be carried out as an effort to improve the internal control system in a higher education institution are:

a. Improving the examination guard system, can be done with an observation system via CCTV, b. Mapped exam rooms well and small groups,

c. Regular monitoring of the lecturer learning process, whether learning in class, routine assignments, or giving grades to students,

d. Validate each exam question,

e. Monitoring and evaluation of academic regulations,

f. Enforcement of sanctions for academic fraud violations

\section{Rationalization Aspects}

The writer concludes that the rationalization aspect is based on sociological and cultural factors. This is based on observations and discussion of the relationship between fraud and rationalization where majority of respondents make strong reasons for fraud because it is carried out jointly and continuously. The only way to break the idea that academic fraud is a justification is by applying strict sanctions that have a deterrent effect on the perpetrators.

Researchers reveal that the rationalization aspect is based on sociological and cultural factors. The habits of respondents who have a history of previous cheating have influenced other students to participate in committing acts of cheating. The justification that has been done and 
discovered since school has led to higher rationalization that is believed by students. Students increasingly feel that cheating is normal and does not have a negative impact on them. This becomes a calculation that only strict sanctions that can provide a deterrent effect and awaken students will stop this cheating behavior.

\section{Capability Aspects}

The aspect of ability as a new aspect has a very influential role in the course of the act of academic fraud. Ability that should be directed to a good interest must end up in a bad way. There are several ways that can be done to direct students' abilities to more useful things, including: improving the learning system in the classroom which not only prioritizes results but also processes, strengthening student character through non-academic activities, giving clear and directed reward punishment to students.

The aspect of ability is an aspect that significantly influences the cheating behavior committed by students. This aspect then becomes the basis for committing fraud because of the belief that their actions will not be detected. Therefore, an increase in the supervision system and internal control system needs to be implemented by institutions so that the gap to cheat is smaller. In addition, lecturer learning strategies need to be updated and continuously improved so that students no longer underestimate the grades they will get and commit cheating.

\section{Arrogancy Aspect}

Students who are considered to have a pride factor in themselves should receive guidance and guidance more from a spiritual and emotional perspective. Often a coach approach is needed to solve this problem. As a new aspect, arrogance has a significant effect on student cheating. Arrogance as a mental aspect suppresses ethics and does not care about the rules that apply. Students who consider themselves great because they commit acts of cheating will keep repeating it again and feel proud of it. Educational institutions need to provide strict sanctions for the perpetrators of fraud, and in still ethical values in the academic process. In addition, there needs to be more respect for the process than just an outcome.

\section{Conclussion}

From the research that has been done, it can be concluded that the act of student academic cheating is a phenomenon that occurs in every university. This act of academic fraud is caused by several aspects. Based on a new theory of cheating, namely the Fraud Pentagon Theory, academic fraud is caused by aspects of pressure, opportunity, rationalization, ability and the aggressiveness of the perpetrators of academic fraud.

The results of the study prove that students commit academic fraud caused by various pressures, including pressure to have good academic grades or achievements. From the pressure they get, students will see the opportunities that exist, namely taking advantage of the leniency of lecturer regulations, the weaknesses of the control and learning systems. To be able to commit cheating without being burdened by ethical conflicts, students need to justify or rationalize their fraudulent behavior. Then the aspect of ability is the reason for a student to commit academic fraud with confidence and courage. Without ability, a student will find it difficult to find the gaps and weaknesses of each lecturer or learning system so that he will not succeed in realizing his academic fraud plan.

Academic fraud is a phenomenon that is rife in tertiary institutions, from cheating on assignments to theses and final assignments. This has the potential to give birth to immoral professionals and justify various ways to achieve personal gain. There are several ways that can 
be done to prevent and minimize student academic fraud, namely: academic guidance, improvement of the learning system to the internal control system, giving strict sanctions to students and improving the quality and supervision of examinations and finally providing activities regarding the balance of IQ, EQ, SQ intelligence., and AQ to students.

The drawback of this research is the limited number of respondents who make this study not yet representing the opinions of every student. The hope for further research is to be able to provide new theories that are more relevant and accurate to identify the causes of students committing academic fraud.

\section{References}

[1] H. M. Santoso and H. Adam, "Analisis Perilaku kecurangan Akademik Pada Mahasiswa Akuntansi Dengan Menggunakan Konsep Fraud Triangle (Studi Pada Mahasiswa S1 Akuntansi Kota Malang," J. Ilm. Mhs. FEB Univ. Brawijawa, vol. 2, no. 2, 2013.

[2] B. D. T. Wolfe and D. R. Hermanson, "Print The Fraud Diamond: Considering the Four Elements of Fraud," vol. 12, no. Exhibit 1.pp. 1-5, 2014. 